\title{
"I Spoke Bahasa Indonesia to My Children so They Would Not Repeat My Experience at School": Why Parents Choose to Talk a Particular Language to Their Children at Home
}

\author{
Abdul Rahman \\ LPMP Sulawesi Tengah, Palu, Indonesia \\ Rahman.bsw@gmail.com
}

\begin{abstract}
Family is the first social institution that introduces language to children. This family will lay foundation of their children's language competence. In a family, parents will indirectly teach their children how and when using the language. They will teach the name of objects, how to deliver their intention and also the appropriateness of a sentence usage. Parents will consciously and unconsciously consider many aspects before introducing particular language to their children that will affect children both socially and academically. Based on these issues, this study aims at exploring two problems. First, to find out why do parents choose particular language to their children at home. Secondly, to find out the impact on this choice toward the children academically. To elicit the problems this study used qualitative research. Purpose sample was employed with 6 participants. The participants were parents with diverse social background. To collect data this study used interview. This study found that parents talk to their children particular language at home for practical reasons: for academic and social reasons. The implication of this research is many children do not speak their ancestor language which may have impact on preservation of the language. However, another consequence arises if they speak their regional language: the children may have problem in their social and academic gain.
\end{abstract}

Keywords: language competence; dialect; interaction

\section{INTRODUCTION}

Indonesia is well known for its multiple ethnics and cultures which includes ethnic languages. It has been recorded that there are 670 ethnic languages exist in the country (Wurm, 2001). However, there is some concern that many of these languages will disappear if there is no preventive action to preserve them. The riskiest languages occur in Eastern Part of Indonesia. Many young generations in the area prefer Bahasa Indonesia to their heritage language. Multamia, A linguist of Universitas Indonesia, (Julikawati, 2015) reported that some ethnic languages in eastern Indonesia such as Moluccas (12 languages) and Papua (2 Language) have been extinct. Meanwhile, Sugiono (n.d.), The Director of Language Development and Preservation Centre of Indonesia, noted 15 regional languages on the verge of extinction. Other ethnic languages will also disappear if there

is no preventive measurement is taken. Sugiono (n.d) reported among most threatened language in Eastern Indonesia, located in Papua and Halmahera (67 regional languages), and Sulawesi (36 languages). Take Central Sulawesi as an example, most of its young generation prefer

speak Bahasa Indonesia to their heritage language. In some areas in this region, Bahasa Indonesia is becoming dominant among its population. Even in school environment, particularly in urban and suburb areas, we will witness students speak among others in Bahasa Indonesia. If these young generations rarely speak their heritage language to their peer, their language eventually will disappear in the coming years.

There is however, the effort made by the government to preserve the lost of local language through education. In some area in Sulawesi region, primary school teachers teach lontarak, an alphabet of Buginese and Makassarness of South Sulawesi Province, for grade 4 and 5 grade. This teaching is actually aims at introducing the writing system to their community in order not to lose it. Yet, in the process, teachers must use Buginese or Makassarnese to explain its usage. Nevertheless, some teaches sometimes switch to Bahasa Indonesia since they are quite familiar with it.

Many researchers have emphasized the role of families to preserve their local language. However, it quite common that many families in Sulawesi region prefer speak Bahasa Indonesia to their ethnic language for their children for some reasons. This preference could threaten the local languages in the area. These languages may disappear if its speakers no longer transmitted to their children. Considering the vital role of family in language preservation, this paper aims at finding out the reasons parents choose particular language to speak with their children at home and whether they have strategy to preserve their heritage language.

\section{THEORETICAL FRAMEWORK}

2.1 Why parents choose to speak particular language to their children

Many researchers are interested in investigating parents' choice of language use at home with their children. In general, two factors could affect the choice. They are internal and external forces. Internal force is the aspiration of parents to use particular language while external factor is the outer driver that requires parents to speak other language to their children.

In terms of internal factors, parents speak particular language to their children for some purposes. The main reason 
parents choose to preserve their heritage language is to connect their family with their culture. The stronger binding of parents toward their previous culture the more they transmit their heritage language to their children. In many cases these parents still expect that they will visit and interact with their previous society in the future (Tatar, 2015).

Relating to external factor, many elements play intertwiningly, including social and political forces. Families, particularly, immigrants, may choose particular language since the host community require them to adopt their culture. For example, Chinese immigrants in Thailand prefer Thai to Mandarin or Hokkian for their children since the Thai expect immigrants to speak and behave like them (Lee, 2014). When these immigrants do not behave like the host society, they will encounter negative consequences such as discrimination and low job opportunity (Lee, 2014). Such social pressure obviously changes these parents' choice to adopt local language for their children. The higher social pressure on them the more family will change their language preference.

Political pressure also affects the use of language use. When a country requires its citizen to speak certain languages, other language could be left by its speakers. For example, in Afghanistan, when the government has overemphasized the use of Pashto and Dari as the official languages of the country for decades, many people do not speak their native language anymore (Singh, Zhang, \& Besmel, 2012).

\section{METHODS}

The current study use phenomenology. Phenomenology is a type qualitative research that attempts to seek the meaning of individual experience on particular phenomena (Morse \& Field, 1996) through oral description of participants (Nieswiadomy, 2011). In this method, interview was used as a main tool to collect data.

The study took place in Palu, Central Sulawesi Province. The total participants of this study were 9 people. The participants consisted of immigrant 5 people $(\mathrm{P} 1, \mathrm{P} 2, \mathrm{P} 3$, $\mathrm{P} 4$, and P5) while 4 others were the native of the region (P6, $\mathrm{P} 7, \mathrm{P} 8$ ). The participant names are replaced with initial $\mathrm{P}$ (participant) to protect their identity. All participants were middle class with their qualification were ranging from associate to master degree. The heritage language of participants is Kailinese, an ethnic language used most in Palu, and Buginese and Torajanese. These two languages are language spoken by immigrants from south Sulawesi Province.

Table 1: Participants' Data

\begin{tabular}{|c|c|c|c|c|}
\hline $\begin{array}{l}\text { Participa } \\
\text { nt } \\
\text { Initial }\end{array}$ & $\begin{array}{l}\text { Residenti } \\
\text { al status }\end{array}$ & $\begin{array}{l}\text { Qualificati } \\
\text { on } \\
\text { (in } \\
\text { Degree) }\end{array}$ & $\begin{array}{l}\text { Typical } \\
\text { Neighborho } \\
\text { od }\end{array}$ & $\begin{array}{l}\text { Home } \\
\text { Languag } \\
\text { e }\end{array}$ \\
\hline P1 & $\begin{array}{l}\text { Immigra } \\
\text { nt }\end{array}$ & Associate & Same ethnic & $\begin{array}{l}\text { Indonesi } \\
\text { an }\end{array}$ \\
\hline $\mathrm{P} 2$ & $\begin{array}{l}\text { Immigra } \\
\text { nt }\end{array}$ & $\begin{array}{l}\text { Junior } \\
\text { High } \\
\text { school } \\
\end{array}$ & Same ethnic & $\begin{array}{l}\text { Indonesi } \\
\text { an }\end{array}$ \\
\hline
\end{tabular}

Table 1, Cont.

\begin{tabular}{lllll}
\hline P3 & Immigrant & Master & Multiethnic & Indonesian \\
\hline P4 & Immigrant & Master & Multiethnic & Indonesian \\
\hline P5 & Immigrant & Bachelor & Multiethnic & Indonesian \\
\hline P6 & Native & Bachelor & Same ethnic & Indonesian \\
\hline P7 & Native & Master & Same Ethnic & Local \\
\hline P8 & Native & Bachelor & Same Ethnic & Indonesian \\
\hline P9 & Native & Bachelor & Same ethnics & Indonesian \\
\hline
\end{tabular}

\section{FINDINGS AND DISCUSSION}

4.1. What factors parents consider in talk particular language to their children

Majority of participants ( 8 out of 9 participants) chose Bahasa Indonesia to communicate with their children at home. Several factors that make them choose Bahasa Indonesia rather that their heritage language have been identified. They are for academic success, social interaction, prestige, and language difference. It should be noted that these choices are not mutual exclusion, but could occur at the same time yet with different level of urgency.

Table 2: The reason parents speak particular language to their children at home

\begin{tabular}{|c|c|c|c|}
\hline $\begin{array}{l}\text { Academic } \\
\text { Success }\end{array}$ & $\begin{array}{l}\text { Social } \\
\text { Connection }\end{array}$ & Prestige & $\begin{array}{l}\text { Language } \\
\text { Difference }\end{array}$ \\
\hline $\begin{array}{l}\text { Make } \\
\text { children } \\
\text { understand } \\
\text { the } \\
\text { instruction at } \\
\text { school (P2) }\end{array}$ & $\begin{array}{l}\text { Easily } \\
\text { communicate } \\
\text { with neighbors } \\
(\mathrm{P} 3, \mathrm{P} 4 \text { \& P8) }\end{array}$ & $\begin{array}{l}\text { Parents } \\
\text { look } \\
\text { cultured } \\
(\mathrm{P} 1)\end{array}$ & $\begin{array}{l}\text { Different } \\
\text { ethnics (P5 \& } \\
\text { P6) }\end{array}$ \\
\hline $\begin{array}{l}\text { Children } \\
\text { understand } \\
\text { when } \\
\text { studying (P1) }\end{array}$ & $\begin{array}{l}\text { Understand } \\
\text { language used } \\
\text { by their } \\
\text { extended family } \\
\text { and ethnics (P4) }\end{array}$ & $\begin{array}{l}\text { Reduce } \\
\text { strong } \\
\text { regional } \\
\text { dialect } \\
(\mathrm{P} 4)\end{array}$ & $\begin{array}{l}\text { Different } \\
\text { level of } \\
\text { Proficiency of } \\
\text { mother } \\
\text { tongue (P7 \& } \\
\text { P9) }\end{array}$ \\
\hline
\end{tabular}

In terms of academic success, two participants explicitly stated that they spoke Bahasa Indonesia to their children since they wanted them easily followed the instruction at school.

“... (The usage of Bahasa Indonesia at home) is to make them easier to understand when studying compared to their parents in the past ... where their teachers should translate the instruction into local language to make them comprehend it". (P1)

Clearly, this participant voiced that different language used between home and school languages makes their children difficult to comprehend the instruction at school. This difficulty is clearly expressed by another participant when she recounted her experience: 
I grew up totally using Buginese. When I entered (a primary) school I didn't understand [the instruction] since my teachers used Bahasa Indonesia. That is why I Spoke Bahasa Indonesia to my children so they would not repeat my experience at school". If we taught our heritage language to the children, even when their teachers try hard to explain it in Bahasa Indonesia, they would still didn't understand it. Because I experienced it [laugh] (P2).

Another participant also illustrated his experience when he was at Elementary School, "I was afraid to ask teachers since I was afraid of making mistake in Bahasa Indonesia" (P7).

This shows that some parents choose Bahasa Indonesia as home language instead of their heritage language for children academic success. The more gaps between language use at home and school will make children difficult to follow the instruction. Language gap between school and children has been believed to hinder student success at school (Spotlsky, 2007). Lack of words as well as different structure will make instruction difficult to comprehend by them. Beside, language gap also prevents children to actively participate at classroom as P7 experience. This is problem is well observed by a researcher (Sara Michael-Luna, 2015), that language gap between home and school prevent students actively participating at learning activity. In addition, many assignments that require Bahasa Indonesia, such as writing short story, may be a difficult task for them since they lack of sufficient words and structure. These problems made children lack behind from their peers whose their home language was Bahasa Indonesia. Realising such problem, these parents believed the necessity to teach Bahasa Indonesia from a very early age.

The second reason participants prefer particular language for their children is for interaction purpose. Some participants were aware that the function of language mastery was to make their children connected to society. This notion is echoed by two participants who use Bahasa Indonesia as their language at home.

P3 who always spoke Buginese to his wife, chose Bahasa Indonesia when speaking with his children. P3 stated that:

"My aim at teaching Bahasa Indonesia was to make my children easily communicate to others. ... Since if I used Buginese, for example, how they would communicate with the neighbors."

Similarly, P4 who live in a multi ethnic neighbourhood argued that "we still use Bahasa Indonesia [not heritage language] because the children will not only interact at home but also interact with the society and at school. It is impossible if we use our ethnic language."

The third reason parents choose Bahasa Indonesia for prestige purpose. For example P1 said:
"From my point of view [if parents used Bahasa Indonesia to their children] it seems their parents looks cultured. It appears like that [laugh].. compared with parents who could not speak bahasa Indonesia at all."

In different way, another participant, $\mathrm{P} 4$ stated:

"Those children do not speak like us anymore. ... to improve the use of Bahasa Indonesia it should follow language principles. Not like their parents. My accent cannot be disappear. I cannot hide it. People will immediately know he must be [a torajanese] [laugh]" (P4).

People usually favour particular dialect over others. Those who speak following the standard dialect are frequently appeared as cultured persons while those who speak differently from the dialect will be stigmatized (Wolfram \& Schilling, 2015) with a negative connotation such as rustic persons. As such, some participants prefer use the standard language or dialect to their children. For example, P4 who speak Indonesian which strong regional accent, use Indonesian to his children at home to prevent his children adopt his accent.

The forth reason why parents speak particular language to their children is language difference between parents. These include ethnics difference (P9) and the mastery level of the language (p6 and P3). P9 who her husband is Sundanese while she is a Buginese spoke Bahasa Indonesia to her children. She said:

"To make it easier for children to understand. I mean so they would not confuse. Since their parents speak two languages, ... the children frequently asked me what language I used when I spoke my heritage language. Likewise, if their father used Sundanese. So, It would be better to use one language [bahasa Indonesia]. It is impossible for example if I used Buginese while their father used Sundanese. At the end, I and their father cannot be connected ." (P9).

When parents come from different ethnics, they immediately aware that speak with their own language is impossible. Therefore, they need communicate with the language they know most. Usually they use lingua franca or the official language. This also applies to their children. They will speak a language comprehend in the family.

Difference mastery level of heritage language also affects the use of language at home. For example, P9 who spoke Kailinese passively. She mostly used Bahasa Indonesia when interacting with her community. Likewise, her husband also knew Kalinese passively. Even though they lived in a majority Kailinese speakers, they spoke Bahasa Indonesia to their language. When asked why she did not speak Kailinese to her children, she responded, "When we were engaging, we used Bahasa Indonesia...[So] we are not accustomed [to use Kailinese]".

When parents want to teach particular language to their children, they surely should proficient in that language. They 
must know the principle of their language before transmitting it to their children. The lack of this proficiency will prevent parents to speak the language to their children.

\subsection{Do they still preserve their heritage language}

Some of participants while spoke Bahasa Indonesia to their children were still concerned of preserving their heritage language for their children. For example P3, he used to communicate with his children around 80 percent Bahasa Indonesia and 20 percent of his heritage language. His reason was " to make them familiar with the language so when they return to Toraja or interact with Torajanese they will not find it difficult to understand it. When people speak Torajanese they will know they mean this." (P3)

From this statement, he still spoke his heritage language in order his children able to interact with their society event in passive way. This indicates that a strong identification with previous community could make parents maintain his heritage language to his children. This connection was also strengthening by his frequent return to Toraja. When returning in Toraja, he and his family would communicate with his relative in Torajanese. Dealing with such situation, he needed to prepare his children at least to comprehend what was said to them.

Other participants did not deliberately use their heritage language at home as P3 did. Instead, they believed that their children eventually would acquire the language when interacting with their community later. L1 stated that, " [Their mother] does not speak Buginese to them. Yet, later, when they interact with the [Buginese] community they will revert back to their heritage language".

This participant assumed that language acquisition will not only occurs at home but also at society. He believed that his children would develop their heritage language once they interact back with their community. Since, he and his family frequently visited his relative in South Sulawesi, his children had a greater chance to expose with his language. The chance of becoming a proficient speaker is greater if the children come in contact with their previous community. As study by Tatar (2015) shows that 'summer vacation' taken by her participant child improved the child' language. Nevertheless, children readiness to learn other language is also determined by their attitude toward the language, the length of interaction and the available opportunity to be exposed to the language.

\section{CONCLUSION}

Parents are crucial agents to preserve their own language. They can do it by frequently use the language to their children. In this study, some factors are considered by participants when choosing a particular language to their children. They are are academic success, social interaction, prestige and the difference proficient level of language being taught.

Some participants had explicit intent to preserve their language. They did it by mixing it with other language to their children at home. However, most participants did not have a clear intent to transmit their heritage language to their children.
Rather, they let their children to learn by their own when they interact with their community.

\section{REFERENCES}

Julikawati, P. E. (2015, June 15). Bahasa Daerah di Indonesia Terus Menyusut [Tempo]. Retrieved September 25, 2016, from https://m.tempo.co/read/news/2015/06/15 /173675198/bahasa-daerah-di-indonesia-terusmenyusut

Lee, H. Y. H. (2014). Losing Chinese As the First Language in Thailand. Asian Social Science, 10(6), 176.

Morse, J. M., \& Field, P. A. (1996). Nursing Research: The Application of Qualitative Approaches. Toronto: Nelson Thornes.

Nieswiadomy, R. M. (2011). Foundations of Nursing Research (6th ed.). Madison Ave, NY: Prentice Hall.

Singh, N. K., Zhang, S., \& Besmel, P. (2012). Globalization and Language Policies of Multilingual Societies: Some Case Studies of South East Asia. Revista Brasileira de Linguística Aplicada, 12(2), 349-380.

Sugiono. (n.d.). Pelindungan Bahasa Daerah dalam Kerangka Kebijakan Nasional Kebahasaan. Retrieved September 25, 2016, from http://badanbahasa.kemdikbud.go.id/laman bahasa/artikel/1343

Tatar, R. (2015). Parents' Role in Their Children's Development and Maintenance of the Heritage Language: A Case Study of a Turkish-American Immigrant Family. Indiana University of Pennsylvania.

Wolfram, W., \& Schilling, N. (2015). American English: dialects and variation (Vol. 25). John Wiley \& Sons.

Wurm, S. A. (2001). Atlas of the World's Languages in Danger of Disappearing. Unesco. 